\title{
Increased oxidative stress in allergic rhinitis. Attention; Ruywayda Adams
}

Hilary Denis Solomons

MB.BCh. M.Med (Haem.). Path) Wits, Johannesburg, South Africa.

Corresponding Author: Hilary Denis Solomons, MB.BCh. M.Med (Haem.). Path) Wits, Johannesburg, South Africa.

Received date: May 26, 2021; Accepted date: August 03, 2021; Published date: August 09, 2021

Citation: Hilary D Solomons. (2021) Increased oxidative stress in allergic rhinitis. Attention; Ruywayda Adams. International Journal of Clinical Case Reports and Reviews. 8(1); DOI:10.31579/2690-4861/142

Copyright: (C) 2021 Hilary Denis Solomons, This is an open-access article distributed under the terms of the Creative Commons Attribution License, which permits unrestricted use, distribution, and reproduction in any medium, provided the original author and source are credited.

There is ample evidence that allergic disorders such as asthma, rhinitis and atopic dermatitis are mediated by oxidative stress.

Excessive exposure to reactive oxygen and nitrogen species is the hallmark of oxidative stress and leads to damage of proteins, lipids and DNA.

Oxidative stress occurs not only as a result of inflammation but also from environmental exposure to air pollution and cigarette smoke.

The specific localization of antioxidant enzymes in the lung and the rapid reaction of nitric oxide with reactive oxygen species, such as superoxide, suggests that antioxidant enzymes might also function as cell-signalling agents or regulators of cell signalling.

Therapeutic interventions that decrease exposure to environmental reactive oxygen species or augment endogenous antioxidant defences might be beneficial as adjunctive therapies in allergic rhinitis.

Allergic rhinitis is an inflammatory disorder of the upper airways. Although several oxidants and antioxidants are likely to be involved, alterations in only limited parameters have been studied,

Oxidative stress reflects an imbalance between the systemic manifestation of reactive oxygen species and a biological system's ability to readily detoxify the reactive intermediates or to repair the resulting damage.

As we have previously shown that asthma is associated with increased oxidant burden and decreased anti-oxidant defence both in the systemic circulation and locally.

Disturbances in the normal redox state of cells can cause toxic effects through the production of peroxides and free radicals that damage all components of the cell, including proteins, lipids and DNA.

Allergic disorders such as rhinitis, asthma as well as atopic dermatitis are mediated by oxidative stress.

Oxidative stress is usually brought on by increased oxidant burden and may well lead to damage to lipids, protein and other systemic elements.

This damage is usually brought on by increased oxidant burden and leads to damage to cellular signals and to cellular messengers.
Usually every part of the body may be targeted.

Superoxide, nitric oxide and their particular reactive product e.g. superoxide dismutase may be infiltrated.

Eosinophils in their thousands may infiltrate the area leading to the aetiology of allergic rhinitis

Eosinophils constitute the major portion of the allergic diathesis.

Diapedesis of leucocytes with toxic granulation parallel this process leading to major degranulation and release of cathepsins A and B.

A major catastrophe may ensue with depletion of Compliment $\mathrm{C} 3$ and a cascade ensues!

Further, some reactive oxidative species act as cellular messengers in redox signalling.

Thus, oxidative stress can cause disruptions in normal mechanisms of cellular signalling.

In allergic rhinitis the immune system uses the lethal effects of oxidants by making production of oxidizing species a central part of its mechanism of killing pathogens; with activated phagocytes producing Reactive Oxygen Species and reactive nitrogen species.

These include superoxide, nitric oxide and their particular reactive product, peroxynitrite.

In allergic rhinitis the highly reactive compounds in the cytotoxic responses of phagocytes cause damage to host tissues, the non-specificity of these oxidants is an advantage since they will damage almost every part of their target cell.

This prevents a pathogen from escaping this part of immune response by mutation of a single molecular target.

Chemically oxidative stress is associated with increased production of oxidizing species or a significant decrease in the effectiveness of antioxidant defences, such as glutathione.

The effects of oxidative stress depend upon the size of these changes, with a cell being able to overcome small perturbations and regain its original 
state.

However, increasing oxidative stress as in allergic rhinitis can cause cell death and even moderate oxidation can trigger apoptosis, while more intense stresses may cause necrosis.

The best studied cellular antioxidants are the enzymes superoxide dismutase (SOD), catalase and glutathione peroxidase.

Peroxiredoxins and sulfiredoxins also important.

Methionine is prone to oxidation but the reaction is reversible.

Oxidation of methionine is shown to inhibit phosphorylation.

This explains the reason that oxidative stress signals with cellular mainstream signalling result in phosphorylation.

In conclusion there is increased oxidative stress in allergic rhinitis!

An imbalance between reactive oxygen species and antioxidants can lead to elevated stress.

Things that increase a person's risk of long term oxidative stress include obesity, diets high in fat, sugar and processed foods ; exposure to radiation. Although several oxidants and anto-oxidants are likely to be involved.

Researchers have established a link between emotional stress and allergic rhinitis flares according to recent study data published in the Journal of allergy, asthma and immumology.

Stress can cause several negative effects on the body including causing more symptoms on allergy sufferers.

Stress worsened allergic rhinitis flares.

If either antioxidants are diminished or production of reactive oxygen species is increased there is increasing evidence of damage to proteins and to lipids! Superoxide dismutase may also be elevated.

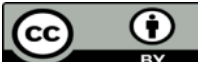

This work is licensed under Creative Commons Attribution 4.0 License

\section{To Submit Your Article Click Here: Submit Manuscript}

DOI: $10.31579 / 2690-4861 / 142$
Ready to submit your research? Choose Auctores and benefit from:

* fast, convenient online submission

* rigorous peer review by experienced research in your field

* rapid publication on acceptance

* authors retain copyrights

* unique DOI for all articles

* immediate, unrestricted online access

At Auctores, research is always in progress.

Learn more www.auctoresonline.org/journals/international-journal-ofclinical-case-reports-and-reviews- 